\title{
Potential Role of $\mathbf{A}_{2 \mathrm{~B}}$ Adenosine Receptors on Proliferation/Migration of Fetal Endothelium Derived from Preeclamptic Pregnancies
}

\author{
Jesenia Acurio, ${ }^{1}$ Felipe Troncoso, ${ }^{1}$ Patricio Bertoglia, ${ }^{1,2}$ Carlos Salomon, ${ }^{3}$ \\ Claudio Aguayo, ${ }^{4}$ Luis Sobrevia, ${ }^{3,5}$ and Carlos Escudero ${ }^{1}$ \\ ${ }^{1}$ Vascular Physiology Laboratory, Group of Investigation in Tumor Angiogenesis (GIANT), \\ Group of Research and Innovation in Vascular Health (GRIVAS Health), Department of Basic Sciences, \\ Faculty of Sciences, Universidad del Bío-Bío, Chillán, Chile \\ ${ }^{2}$ Obstetrics and Gynecology Department, Herminda Martin Clinical Hospital, Chillan, Chile \\ ${ }^{3}$ University of Queensland Centre for Clinical Research (UQCCR), Faculty of Medicine and Biomedical Sciences, \\ University of Queensland, Herston, QLD 4006, Australia \\ ${ }^{4}$ Department of Clinical Biochemistry and Immunology, Faculty of Pharmacy, University of Concepción, Chile \\ ${ }^{5}$ Cellular and Molecular Physiology Laboratory (CMPL), Division of Obstetrics and Gynecology, Faculty of Medicine, \\ School of Medicine, Pontificia Universidad Católica de Chile, Santiago, Chile
}

Correspondence should be addressed to Carlos Escudero; cescudero@ubiobio.cl

Received 13 December 2013; Accepted 1 April 2014; Published 28 April 2014

Academic Editor: Gregory Rice

Copyright @ 2014 Jesenia Acurio et al. This is an open access article distributed under the Creative Commons Attribution License, which permits unrestricted use, distribution, and reproduction in any medium, provided the original work is properly cited.

To investigate the functionality of $A_{2 B}$ adenosine receptor $\left(A_{2 B} A R\right)$ and the nitric oxide $(N O)$ and vascular endothelial growth factor (VEGF) signaling pathway in the endothelial cell proliferation/migration during preeclampsia, we used human umbilical vein endothelial cells (HUVECs) isolated from normal pregnancies $(n=15)$ or pregnancies with preeclampsia $(n=15)$. Experiments were performed in presence or absence of the nonselective adenosine receptor agonist NECA, the $\mathrm{A}_{2 \mathrm{~B}} \mathrm{AR}$ selective antagonist MRS-1754, and the nitric oxide synthase (NOS) inhibitor L-NAME. Results indicated that cells from preeclampsia exhibited a significant higher protein level of $\mathrm{A}_{2 \mathrm{~B}} \mathrm{AR}$ and $\operatorname{logE\mathrm {C}_{50}}$ for NECA-mediated proliferation than normotensive pregnancies. The stimulatory effect of NECA $(10 \mu \mathrm{M}, 24 \mathrm{~h})$ on cell proliferation was prevented by MRS-1754 $(5 \mathrm{nM})$ coincubation only in cells from normotensive pregnancies. Nevertheless, L-NAME $(100 \mu \mathrm{M}, 24 \mathrm{~h})$ reduced the NECA-induced cell proliferation/migration in HUVEC from normal pregnancy; however in preeclampsia only NECA-induced cell proliferation was reduced by L-NAME. Moreover, NECA increased protein nitration and abundance of VEGF in cells from normal pregnancy and effect prevented by MRS-1754 coincubation. Nevertheless, in preeclampsia NECA did not affect the protein level of VEGF. In conclusion HUVECs from preeclampsia exhibit elevated protein level of $A_{2 B} A R$ and impairment of $A_{2 B} A R$-mediated NO/VEGF signaling pathway.

\section{Introduction}

Preeclampsia is the leading cause for maternal and neonatal morbidity and mortality worldwide [1]. The pathophysiology of the fetal complications in preeclampsia is still unclear, but it has been associated with placental alterations compatible with under perfusion $[2,3]$ and reduced placental blood flow [4], which in turn may limit the delivery of nutrients to the fetus. Since placental and proximal umbilical vessels lack innervation [5], the regulation of vascular blood flow depends on the synthesis and release of endothelial vasoactive molecules, such as nitric oxide (NO) and adenosine [6-8]. In this regard, several evidences suggest that preeclampsia is characterized by endothelial dysfunction in both maternal [ 9 , 10] and fetoplacental circulation [11-14], which may impair not only vascular tone regulation but also angiogenesis.

Adenosine is a naturally occurring nucleoside, which controls several physiological processes including vascular 
tone regulation and angiogenesis $[15,16]$, via activation of G-protein-coupled adenosine receptors (AR) [16]. Four types of $A R$ have been identified: $A_{1} A R, A_{2 A} A R, A_{2 B} A R$, and $A_{3} A R$ $[16,17]$. At the physiological nanomolar range, adenosine mainly activates $A_{1} A R, A_{2 A} A R$, and $A_{3} A R$, whereas $A_{2 B} A R$ requires micromolar concentrations [18]. Nevertheless, exposure of any AR to agonists for shorter or longer times generally leads to the attenuation of the agonist response. In this regard, desensitization of $\mathrm{A}_{2 \mathrm{~B}}$ receptor has been described in different cell lines (see details in [18]), but little is known regarding $\mathrm{A}_{2 \mathrm{~B}} \mathrm{AR}$ desensitization during human diseases.

In the fetoplacental circulation from preeclampsia, elevated level of adenosine has been reported in umbilical vein (1.7 versus $0.5 \mu \mathrm{mol} / \mathrm{L}$, preeclampsia versus normal pregnancy, resp.) $[19,20]$ and in culture medium of human placental microvascular endothelial cells (hPMEC) (2.7 versus $0.6 \mu \mathrm{mol} / \mathrm{L}$, preeclampsia versus normal pregnancy, resp.) [7], suggesting that under this pathological condition all subtypes of adenosine receptor would be activated [18]. However, little is known regarding the potential role of adenosine receptors in the regulation of placental homeostasis during preeclamptic pregnancies. In particular, regarding $A_{2 B} A R$, high levels of this receptor have been reported in total placental homogenate [21], but no changes in hPMEC [7] derived from preeclampsia compared to normal pregnancy. Interestingly, elevated adenosine uptake seen in hPMEC from preeclampsia reverted by $\mathrm{A}_{2 \mathrm{~A}} \mathrm{AR} / \mathrm{A}_{2 \mathrm{~B}} \mathrm{AR}$ inhibitors, suggest a tonic activation of adenosine transport by these receptors in preeclamptic pregnancies [7]. Nevertheless, other groups have reported that activation of $\mathrm{A}_{2 \mathrm{~B}} \mathrm{AR}$ in HUVEC exposed to hypoxia [22] or not is associated with upregulation of proangiogenic factors such as vascular endothelial growth factor (VEGF) [23-26] and $\mathrm{NO}$ [27]. Stimulation of $\mathrm{A}_{2 \mathrm{~B}} \mathrm{AR}$ increases proliferation of several cell types including porcine, rat endothelium [28], and human retinal endothelial cell [15]. Notwithstanding, in HUVEC from preeclampsia occurring before 34 weeks of gestation, we have described reduced cell proliferation associated with decreased activation of $\mathrm{A}_{2 \mathrm{~A}} \mathrm{AR} / \mathrm{NO}$ signaling pathway compared to controls [29]. Despite these evidences, it is unknown whether preeclampsia may affect the proangiogenic role of $\mathrm{A}_{2 \mathrm{~B}} \mathrm{AR}$ in fetal endothelium.

We propose that HUVECs isolated from preeclamptic pregnancies exhibit reduced activation of $\mathrm{A}_{2 \mathrm{~B}} \mathrm{AR}$ compared to normal pregnancy.

\section{Patients and Methods}

2.1. Reagents. Unless otherwise indicated, all reagents were purchased form Sigma-Aldrich (MO, USA): nonselective agonist for adenosine receptors, NECA, $5^{\prime}$-(N-ethylcarboxamido) adenosine; selective $\mathrm{A}_{2 \mathrm{~B}} \mathrm{AR}$ antagonist, MRS-1754, 8-\{4-\{((4-cyanophenyl) carbamoylmethyl)oxy\} phenyl $\}-1,3-$ di(n-propyl) xanthine hydrate; nonselective inhibitor of nitric oxide synthase, L-NAME, $\mathrm{N}_{\omega}$-nitro-L-arginine methyl ester hydrochloride; antibodies: anti- $\mathrm{A}_{2 \mathrm{~B}} \mathrm{AR}$ (Santa Cruz Biotechnology, CA, USA); antinitrotyrosine (Merck
Millipore, MA, USA); anti-eNOS (Transduction Laboratories, NJ, USA), anti-VEGF (Cell Signaling, MA, USA), and anti- $\beta$-actin (Sigma Aldrich, MO, USA).

2.2. Patients. The Ethical Committee from the Universidad del Bío-Bío approved this cohort study and the informed consent was obtained from each participant. Pregnant women who attended to the Obstetrics and Gynecology Department of the Herminda Martin Clinical Hospital, Chillan, Chile, for their delivery were included in this study. Exclusion criteria included chronic hypertension, altered renal function, diabetes, chronic diseases, twin pregnancies, recurrent miscarriages, and abruption placenta. Women were classified into normal pregnancy (maternal blood pressure < $140 / 90 \mathrm{mmHg}$, absence of proteinuria, and no medical complications) and preeclampsia (new onset hypertension defined as blood pressure $\geq 140 / 90 \mathrm{mmHg}$, with at least 2 measurements $6 \mathrm{~h}$ apart, and proteinuria $>300 \mathrm{mg} / 24$ hours after 20 weeks of gestation). The gestational age was defined as the period of time from the first day of the mother's last menstrual period and the delivery date, confirming this age by a first trimester ultrasound. Moreover, according to the standard protocol, all patients with preeclampsia received antihypertensive treatment and magnesium sulfate to prevent convulsions in case of severe preeclampsia. Diagnosis of small gestational age was performed when the newborn weight was $<10$ th percentile to Chilean population [30].

2.3. HUVEC Culture. Endothelial cells were isolated from the human umbilical vein by digestion with collagenase $(0.25 \mathrm{mg} / \mathrm{mL})$ and then cultured $\left(37^{\circ} \mathrm{C}, 5 \% \mathrm{CO}_{2}\right)$ in medium 199 (M199) as previously described [31]. All experiments were performed in duplicate, after overnight serum deprivation and in presence of adenosine deaminase (ADA $1 \mathrm{IU} / \mathrm{mL}$ ) (Merck Millipore, Darmstadt, Germany). Cells were used in passage 2 .

2.4. Cell Proliferation and Migration. Cell proliferation was analyzed after treatment $(24 \mathrm{~h})$ with NECA $(10 \mu \mathrm{M})$ and/or MRS-1754 $(5 \mathrm{nM})$ or L-NAME $(100 \mu \mathrm{M})$ by using 3-(4,5-dimethylthiazol-2-yl)-5-(3-carboxymethoxyphenyl)2-(4-sulfophenyl)-2H-tetrazolium (MTS) assay following the manufacture instruction (Promega, WI, USA) as described previously [29]. Moreover, in parallel experiments, cell migration was analyzed by transwell chambers assay as described elsewhere. In brief, HUVECs were trypsinized and seeded in the upper compartment of the transwell (Corning, NY, USA) at a density of $150 \times 10^{3}$ cells/well in M199. The lower compartments were loaded with culture medium (control) or AR agonist and/or antagonist. After 24 hours, cells that had migrated to the bottom of the transwell membrane $(8 \mu \mathrm{m})$ were stained using hematoxylin (Winkler, Santiago, Chile). Membranes were observed at 40x magnification using a light microscope (Olympus, Tokyo, Japan) and 3 photos were taken from each preparation [29]. In addition, both cell proliferation and migration were measured in a concentration-response curve in presence of NECA. 
2.5. Immunocytochemistry. The presence of $\mathrm{A}_{2 \mathrm{~B}} \mathrm{AR}$ in HUVECs was evidenced by immunocytology following the manufacturers protocol (Vector Laboratories, CA, USA), as described previously [29]. Briefly, HUVECs were fixed in $4 \%$ paraformaldehyde prepared in phosphate buffer (PBS (mM): $\mathrm{NaCl}$ 13.7, KCl 2.7, $\mathrm{Na}_{2} \mathrm{HPO}_{4}$ 0.9, $\mathrm{KH}_{2} \mathrm{PO}_{4}$ 1.8, $\mathrm{pH}$ $7.4,4^{\circ} \mathrm{C}$ ) for 20 minutes. After blocking unspecific binding, cell preparations were incubated overnight with primary $\mathrm{A}_{2 \mathrm{~B}} \mathrm{AR}$ antibody $(1: 200 \mathrm{v} / \mathrm{v})$ followed by incubation with respective secondary antibody $(1: 500 \mathrm{v} / \mathrm{v})$ diluted in PBS with 5\% serum. Antigen-antibody reaction was further revealed by diaminobenzidine reaction (DAB). Analysis was blinded and performed using a bright field microscope (Olympus, Tokyo, Japan). For densitometric analysis three random pictures from each preparation were taken using a digital camera (Guangzhou Micro-shot Technology Co., Ltd, Guangdong, China). Estimation of the intensity of staining in the pictures was analyzed using Image software $(\mathrm{NIH}$, MD, USA) after light calibration and color deconvolution as previously described [32]. Values are expressed as the ratio of the area of positive brown stain divided by the total area of the reference field.

2.6. Western Blot. Cell, protein extracts $(70 \mu \mathrm{g})$ were separated by SDS-PAGE (10\%) transferred to nitrocellulose membranes and probed with primary anti- $\mathrm{A}_{2 \mathrm{~B}} \mathrm{AR}(1: 2000 \mathrm{v} / \mathrm{v})$, antinitrotyrosine $(1: 3000 \mathrm{v} / \mathrm{v})$, anti-eNOS $(1: 2000 \mathrm{v} / \mathrm{v})$, anti$\operatorname{VEGF}(1: 3000 \mathrm{v} / \mathrm{v})$, and anti- $\beta$-actin $(1: 10000 \mathrm{v} / \mathrm{v})$ antibodies diluted in PBS with $0.1 \%$ Tween (pH 7.4) and 5\% milk. Then, a horseradish peroxidase-conjugated secondary antibody was used for visualization [29]. Secondary antibody was selected according to respective primary antibody. Dilution range of secondary antibody was $1: 2000$ to $1: 150000 \mathrm{v} / \mathrm{v}$ in PBS/Tween buffer ( $\mathrm{pH} 7.4$ ) with 5\% milk.

2.7. Nitrite Measurement. Nitrite levels were measured by the Griess reaction using a commercially available kit (Promega, WI, USA). In brief, confluent cells were incubated (30 min) in the presence or absence of NECA $(10 \mu \mathrm{M})$ and/or MRS1754 ( $5 \mathrm{nM}$ ); and then, $100 \mu \mathrm{L}$ of M199 was collected for nitrite quantification in a spectrophotometer (Autobio, Zhengzhou, China) using a $540 \mathrm{~nm}$ filter [29].

2.8. Statistical Analysis. Comparisons between groups were performed by the Mann-Whitney test. We used $X^{2}$ test to analyze proportions. Values are mean \pm S.E.M., where $n$ indicates number of different cell cultures (in duplicate). $P<0.05$ is considered statistically significant. The statistical software GraphPad Instat 3.01 and GraphPad Prism 5.00 (GraphPad Software Inc., California, USA) were used for data analysis.

\section{Results}

3.1. Clinical Characteristics of Patients. Thirty women were included in the study divided into normal pregnancies $(n=$ $15)$ and preeclampsia $(n=15)$. Compatible with diagnostic criteria, women with preeclampsia exhibited higher
TABLE 1: Characteristics of the included women.

\begin{tabular}{lcc}
\hline & $\begin{array}{c}\text { Normal } \\
(n=15)\end{array}$ & $\begin{array}{c}\text { Preeclampsia } \\
(n=15)\end{array}$ \\
\hline Age (years) & $25.1 \pm 1.6$ & $26.5 \pm 1.7$ \\
BMI at delivery $\left(\mathrm{kg} / \mathrm{m}^{2}\right)$ & $31.4 \pm 1.3$ & $33.5 \pm 1.4$ \\
GA at delivery $(\mathrm{wk})$ & $39.4 \pm 0.3$ & $37.4 \pm 0.3^{*}$ \\
SBP $(\mathrm{mmHg})$ & $115.2 \pm 1.5$ & $161.9 \pm 4.8^{*}$ \\
DBP $(\mathrm{mmHg})$ & $72.7 \pm 1.7$ & $102.1 \pm 2.3^{*}$ \\
Proteinuria, g/24h & 0 & $2.2 \pm 1.0^{*}$ \\
Newborn & & \\
$\quad$ Male/female & $7 / 8$ & $7 / 8$ \\
$\quad$ Weight $(\mathrm{g})$ & $3333 \pm 111.3$ & $2726 \pm 178.8^{*}$ \\
Height $(\mathrm{cm})$ & $48.8 \pm 0.4$ & $46.3 \pm 0.7^{*}$ \\
SGA, $n(\%)$ & 0 & $4(27)^{*}$ \\
Cephalic perimeter $(\mathrm{cm})$ & $34.1 \pm 0.2$ & $33.3 \pm 0.6$ \\
Placenta & & $490.0 \pm 34.6$ \\
$\quad$ Weight $(\mathrm{g})$ & $542.7 \pm 33.5$ & $2.8 \pm 0.2$ \\
Area $\left(\mathrm{m}^{2}\right)$ & $3.3 \pm 0.3$ & $5.7 \pm 0.2$ \\
NBW/PlW (g/g) & $6.3 \pm 0.3$ & \\
\hline
\end{tabular}

BMI: body mass index; SBP: systolic blood pressure; DBP: diastolic blood pressure; SGA: small for gestational age $(<10$ th percentile according to gestational age); NBW: newborn weight; GA: gestational age; PlW: placental weight. ${ }^{*} P<0.05$ versus normal pregnancy. Values are mean \pm SEM.

systolic and diastolic blood pressure than normal pregnancy (Table 1). Gestational age at delivery, newborn weight, and height were lower in preeclampsia than normal pregnancy. $27 \%$ of pre-eclamptic women had small for gestational age babies. Despite the trend to lower placental weight in preeclampsia, it was not statistically significant compared to controls (Table 1).

3.2. Functional Characterization of $A_{2 B} A R$. Western blot and immunocytology showed significantly higher (1.6 and 1.7, resp.) $A_{2 B} A R$ protein levels in HUVEC from preeclampsia than those from normal pregnancy (Figure 1). In the presence of NECA $(10 \mu \mathrm{M}, 24 \mathrm{~h})$, it was observed a significant elevation in both proliferation (Figure 2(a)) and migration (Figure 2(b)) of HUVEC from normal and preeclamptic pregnancies. Moreover, NECA-induced cell proliferation was not observed when cells derived from normal pregnancies were coincubated with MRS-1754. However, in cells from preeclampsia, coincubation with NECA and MRS1754 exhibited similar response to NECA alone. In addition, MRS-1754 did not affect cell proliferation in normal or preeclamptic pregnancies.

The effect of NECA on cell proliferation was also tested in a concentration-response curve in both normal and preeclamptic derived cells (Figure 3). The calculated logarithmic $\mathrm{EC}_{50}\left(\operatorname{LogEC} \mathrm{C}_{50}\right)$ for NECA was significantly higher $(-7.7 \pm 0.5$ and $-9.6 \pm 0.7 \mathrm{M}$, resp.; $P<0.05)$ in preeclampsia compared to normal pregnancy.

Regarding cell migration, despite the stimulatory effect observed after NECA incubation was similar in both normal and preeclamptic cells compared to its respective basal condition (1.5- and 1.4-fold, resp.), it was observed that cells 

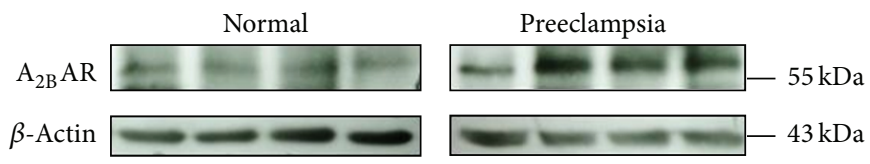
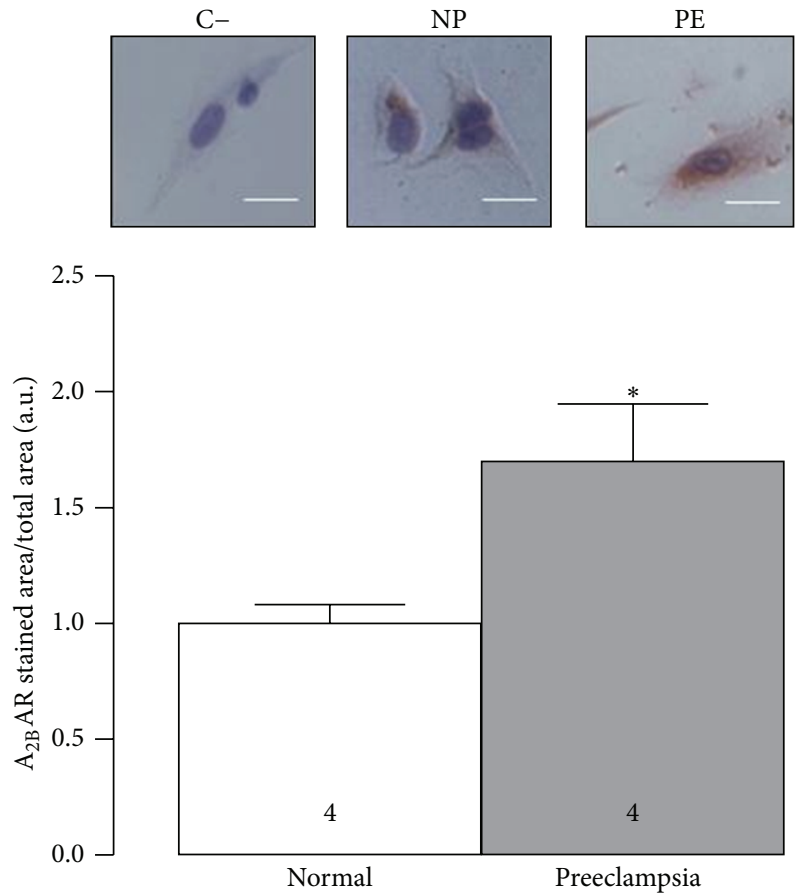

(b)

FIGURE 1: Protein levels of $\mathrm{A}_{2 \mathrm{~B}} \mathrm{AR}$ in both normal and preeclamptic cells. (a) Cells derived from normal (NP) or preeclamptic pregnancies (PE) were used for estimating protein abundance of $A_{2 B} A R$ by western blot. Upper panel shows representative images of $A_{2 B} A R$ protein $(55 \mathrm{kDa})$ and $\beta$-actin $(43 \mathrm{kDa})$. Bottom panel shows densitometry of $A_{2 \mathrm{~B}} \mathrm{AR} / \beta$-actin ratio. (b) Upper panel shows representative images of immunocytochemistry for $\mathrm{A}_{2 \mathrm{~B}} \mathrm{AR}$. Bottom panel included the ratio of the digital analysis of the stained area by $\mathrm{A}_{2 \mathrm{~B}} \mathrm{AR}$ divided by total area as described in Section 2. Line in the photos represents $5 \mu \mathrm{M} .{ }^{*} P<0.05$ versus respective value in normal pregnancy. C- is negative control without primary antibody. Values are mean \pm SEM. Respective $n$ is indicated in each bar. All experiments were performed in duplicate.

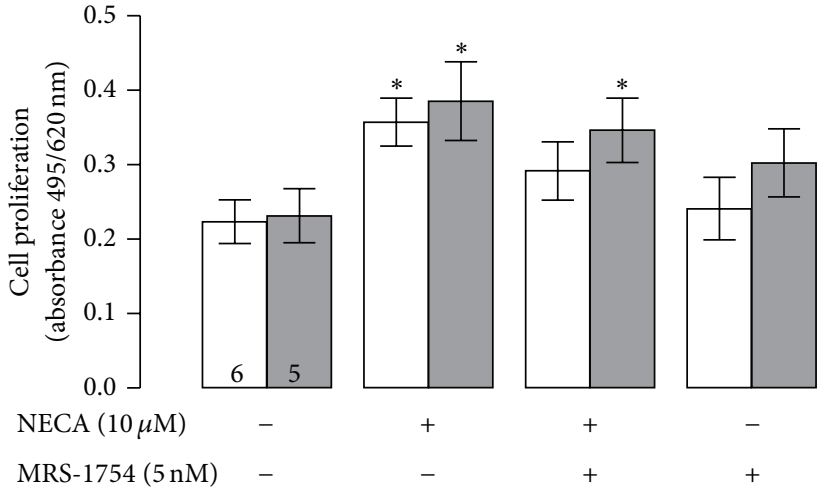

(a)

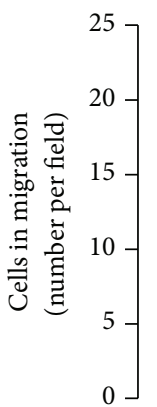

$\operatorname{NECA}(10 \mu \mathrm{M})$

MRS-1754 (5 nM)

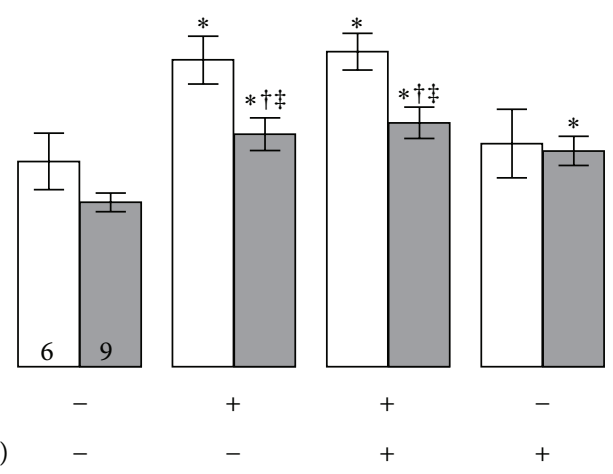

(b)

FIGURE 2: Cell proliferation and migration induced by $\mathrm{A}_{2 \mathrm{~B}} \mathrm{AR}$. HUVECs were isolated from normal (white bars) and preeclamptic pregnancies (grey bars) and used for (a) analysis of cell proliferation by MTS assay in presence (+) or absence (-) of NECA (10 $\mu \mathrm{M}, 24 \mathrm{~h})$ and/or MRS-1754 $(5 \mathrm{nM}, 24 \mathrm{~h})$ or (b) cell migration as described in (a). ${ }^{*} P<0.05$ versus basal condition in normal pregnancy. ${ }^{\dagger} P<0.05$ versus basal condition in preeclampsia. ${ }^{\ddagger} P<0.05$ versus respective value in normal pregnancy. Values are mean $\pm S E M$. Values in respective control column indicate $n$. All experiments were performed in duplicate.

from preeclampsia do not reach similar response compared to normal pregnancy (Figure 2(b)). In fact, migratory response was $29 \pm 3 \%$ less in cells from preeclampsia compared to normal pregnancy. NECA-mediated cell migration was not affected by MRS-1754 co-incubation in cell from normal or pre-eclamptic pregnancies. Yet, cells from preeclampsia exposed to MRS-1754 alone exhibit a significant increase (1.3-fold) in cell migration compared to its basal condition without any treatment, whereas no effect was observed in cells from normal pregnancy incubated with this antagonist. 


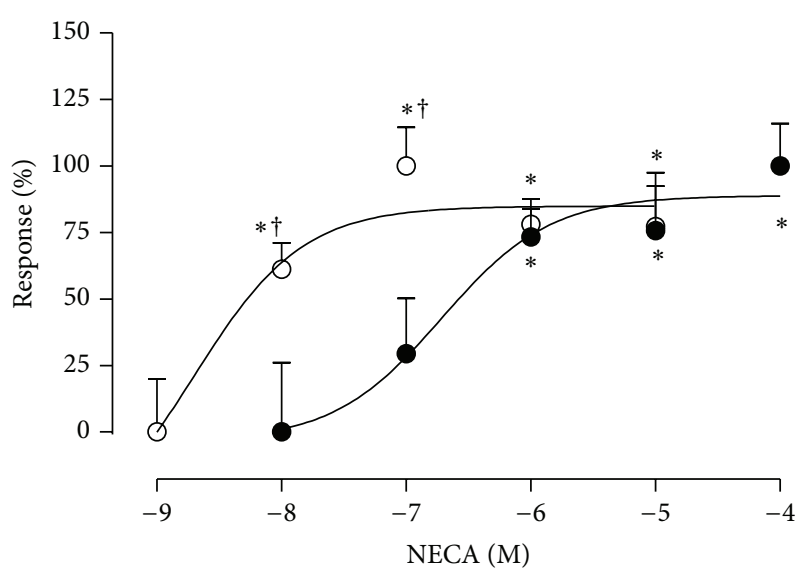

FIgURE 3: Cell proliferation induced by NECA in a concentrationresponse curve. HUVEC was isolated from normal (open circles, $n=$ 6) and preeclamptic pregnancies (closed circles, $n=3$ ) and used for cell proliferation in presence of NECA $\left(10^{-9}\right.$ to $\left.10^{-4} \mathrm{M}, 24 \mathrm{~h}\right)$. ${ }^{*} P<0.05$ versus respective low NECA concentration. Values are mean \pm SEM. All experiments were performed in duplicate.

3.3. $A_{2 B} A R$ Stimulation and NO. There were no differences in the protein abundance of endothelial nitric oxide synthase (eNOS) between preeclampsia and normal pregnancies (Figures 4(a) and 4(b)). Moreover, neither NECA (10 $\mu \mathrm{M})$ nor MRS-1754 incubation ( $5 \mathrm{nM}, 12 \mathrm{~h}$ ) changed the protein abundance of eNOS in either preeclampsia or normal pregnancy.

Nevertheless, during short incubations (30 min), NECA induce nonstatistically significant reduction in the nitrite levels measured in culture medium (Figure 4(c)), as well as a significant elevation in the intracellular nitrotyrosine formation (Figure 4(d)) in HUVEC from both preeclampsia and normal pregnancy. Moreover, coincubation of NECA + MRS-1754 was associated with reduction in the nitrite level only in preeclamptic cells. Furthermore, NECA-mediated nitrotyrosine formation observed in cells from normal or preeclamptic pregnancies was not blocked by MRS-1754.

In addition, increase in cell proliferation induced by NECA in normal or pre-eclamptic pregnancies (1.9 and 1.7 fold, resp.) (Figure 5(a)) was partially reduced by coincubation with L-NAME $(100 \mu \mathrm{M})$. Furthermore, when the percentage of reduction mediated by L-NAME coincubation was calculated, it was observed that normal pregnancy derived cells exhibited a higher percentage $(38 \pm 2 \%)$ than preeclampsia $(18 \pm 1 \%)\left(\chi^{2}=8.9, P<0.05\right)$. Nevertheless, combination of L-NAME and MRS-1754 reduced in $43 \pm 1 \%$ and $29 \pm 1 \%$ the NECA-mediated augmentation in cell proliferation in normal and preeclamptic HUVEC, respectively (data not shown). On the other hand, L-NAME induces a partial reduction $(27 \pm 4 \%)$ in the stimulatory effect of NECA on cell migration, whereas no affect was observed in preeclampsia (Figure 5(b)).

3.4. $A_{2 B} A R$ Stimulation and VEGF. There were no significant differences in the protein level of VEGF in HUVEC derived from normal and preeclampsia. After stimulation with NECA $(10 \mu \mathrm{M}, 12 \mathrm{~h})$, cells from normal pregnancies exhibited an increase (1.7-fold) in the VEGF protein abundance compared to corresponding controls without any treatment. The latter effect of NECA was not observed in cells coincubated with MRS-1754 (5 nM). Contrarily, neither NECA nor MRS1754 alone or in combination affected the VEGF protein level in preeclampsia (Figures 6(a) and 6(b)).

3.5. NO and VEGF Expression. The stimulatory effect of NECA $(10 \mu \mathrm{M}, 12 \mathrm{~h})$ on VEGF protein levels was partially blocked by L-NAME or MRS-1754 (Figures 6(c) and 6(d)). Interestingly, the reductive effect of these last two inhibitors upon NECA effect was more than additive since cell coincubated with L-NAME, MRS-1754, and NECA exhibited reduced VEGF levels even below control condition without any treatment.

\section{Discussion}

Results presented in this work describe that HUVEC from preeclampsia exhibits elevated protein level of $\mathrm{A}_{2 \mathrm{~B}} \mathrm{AR}$ compared to normal pregnancy. However, functionality of this receptor may be reduced in preeclampsia. This is supported by results showing a shift in the concentration-response curve to NECA during cell proliferation, where $\operatorname{logEC_{50}}$ is higher in preeclampsia than normotensive pregnancies. In addition, a reduced migratory response to NECA was seen in preeclampsia compared to normal pregnancy; and contrary to cell from normal pregnancy, in pre-eclampsia the expression of VEGF associated with $\mathrm{A}_{2 \mathrm{~B}} \mathrm{AR}$ stimulation was absent. Results from coincubation of agonist and antagonists suggest that activation of $\mathrm{A}_{2 \mathrm{~B}} \mathrm{AR}$ triggers intracellular pathways involving protein nitration, which may participate in cell proliferation/migration and VEGF protein expression in HUVEC from normal pregnancies. However, in preeclampsia only cell proliferation seems to be associated with protein nitration induced by $\mathrm{A}_{2 \mathrm{~B}} \mathrm{AR}$. In conclusion, HUVECs from preeclampsia exhibit elevated protein level of $\mathrm{A}_{2 \mathrm{~B}} \mathrm{AR}$. Moreover, tyrosine nitration and VEGF protein expression mediated by $\mathrm{A}_{2 \mathrm{~B}}$ are associated with cell proliferation/migration in normal cells, but this cell signaling is impaired in preeclampsia.

4.1. Clinical Context. Preeclamptic placenta exhibits reduced fetoplacental blood flow [4], generated by placental under perfusion $[2,3]$ associated with limited placental invasion into maternal spiral arteries [33] and impaired remodeling process of those vessels [34]. Furthermore, hemodynamic changes generated by those alterations in the maternalplacental interphase may generate a turbulent blood flow that hits the placenta and leads to impaired placental villi architecture [35], then compromising the fetoplacental circulation in preeclampsia [4]. All these alterations have been associated with generation of oxidative and nitrative stress within the placenta $[36,37]$, leading to endothelial dysfunction in the fetoplacental circulation [11-14]. Others and we believe that part of this endothelial dysfunction present in the preeclamptic placenta may include alteration in the angiogenesis process $[3,4,14,29,38]$, which in turn 


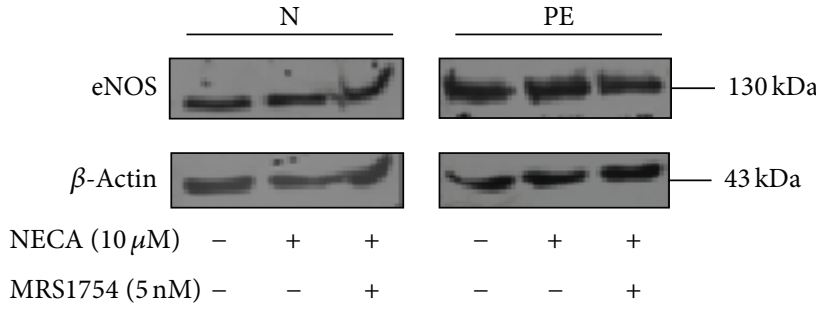

(a)

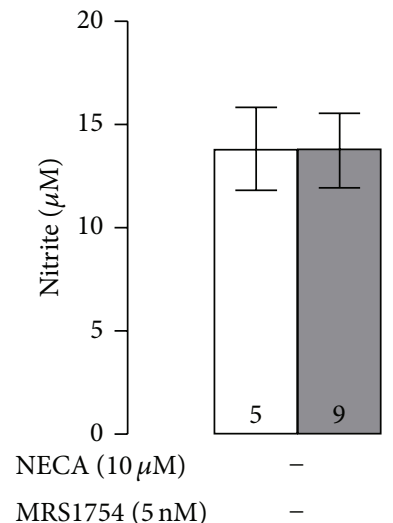

(c)
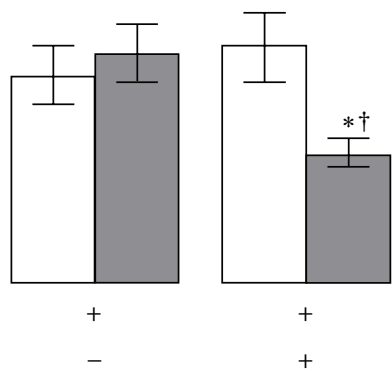

$+$

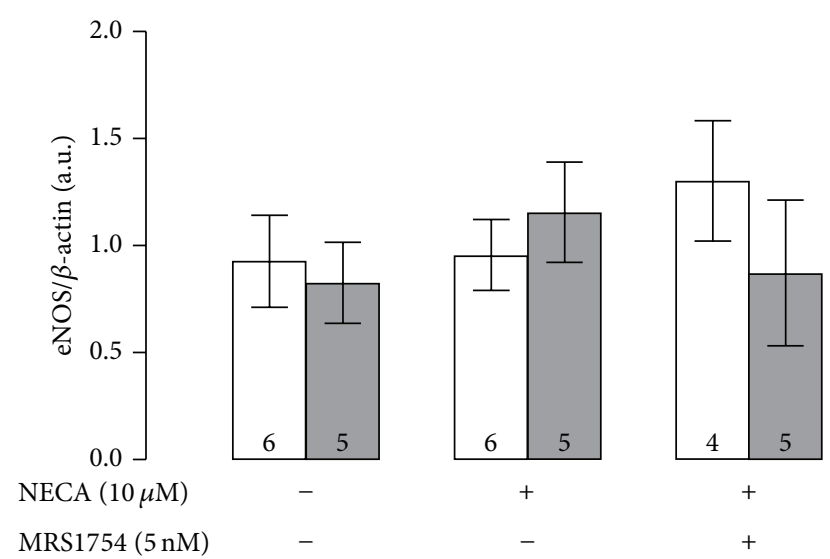

(b)

$\mathrm{N}$
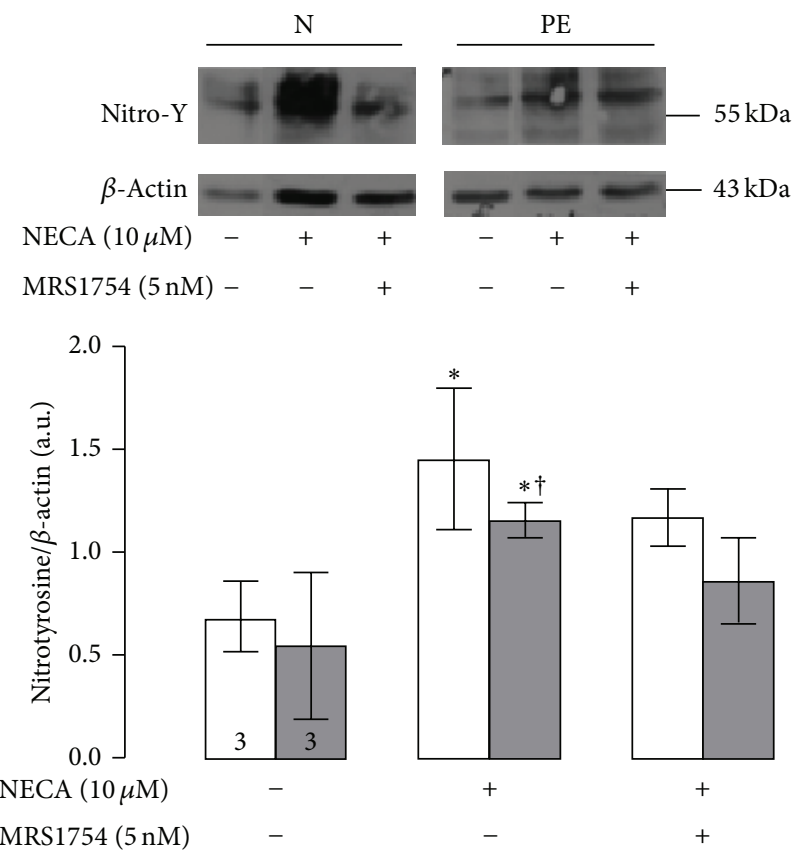

(d)

FIGURE 4: Stimulation of $\mathrm{A}_{2 \mathrm{~B}} \mathrm{AR}$ generates nitrotyrosine formation. (a) Representative images of western blots for endothelial nitric oxide synthase (eNOS, $130 \mathrm{kDa})$ and $\beta$-actin $(43 \mathrm{kDa})$ in absence $(-)$ or presence $(+)$ of NECA $(10 \mu \mathrm{M})$ and/or MRS-1754 (5 nM) during 12 hours in cells from normal (N) or preeclamptic pregnancies (PE). (b) Densitometry of the eNOS/ $\beta$-actin ratio as showed in (a). (c) Nitrite concentrations in homogenate of cell after incubation (30 min) with NECA (10 $\mu \mathrm{M})$ and/or MRS-1754 (5 nM). (d) Upper panel, representative images of western blots for nitration of tyrosine residues (Nitro-Y) in protein(s) at $55 \mathrm{kDa}$ and $\beta$-actin $(43 \mathrm{kDa})$. Bottom panel presents the densitometry of the nitrotyrosine/ $\beta$-actin ratio in the analyzed groups as showed in the upper panel. In (c) and (d), ${ }^{*} P<0.05$ and ${ }^{\dagger} P<0.05$ versus value in basal condition (i.e., without any treatment) of normal pregnancy or preeclampsia, respectively. Values are mean \pm SEM. Values in respective column indicate $n$. All experiments were performed in duplicate.

could explain the elevated risk for short and long term complications observed in children exposed to preeclampsia intrauterine. Regarding short-term complication associated to preeclampsia, clinical data presented in this study, showing that preeclamptic women exhibited high blood pressure (mean value 161/102 $\mathrm{mmHg}$ ), associated with reduced gestational age and 4 of 15 preeclamptic women had a baby small for gestation age. Although we did not analyze the data according to the severity of the disease or gestation age of presentation, our study describes major differences in the $\mathrm{A}_{2 \mathrm{~B}} \mathrm{AR} / \mathrm{NO} / \mathrm{VEGF}$ signaling pathway when cells from preeclampsia are compared with those derived from normotensive pregnancies. However, the impact of confounding variables including degree of severity of the disease, gestational age at onset, treatment received, and children sex should be addressed in future studies.

4.2. Adenosine and HUVEC Proliferation/Migration. Adenosine promoted angiogenesis. The underling mechanisms are 


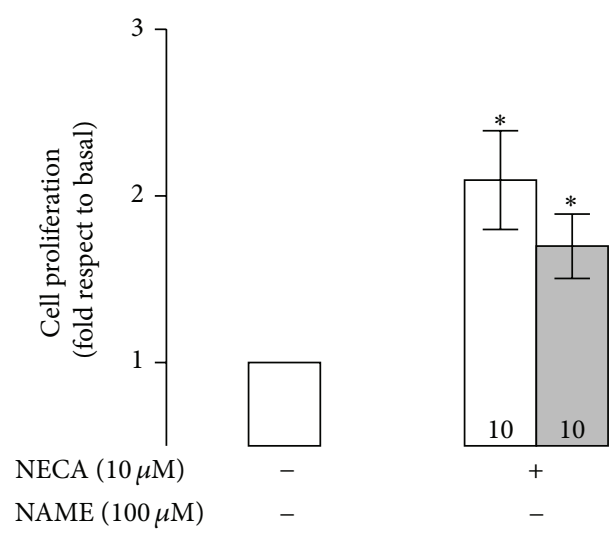

(a)

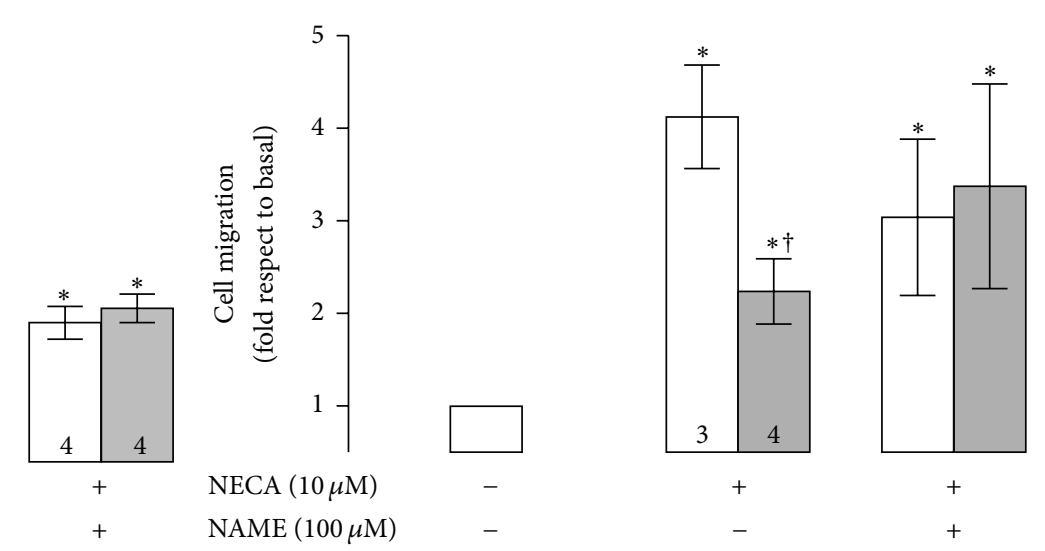

(b)

FIGURE 5: Effects of NOS inhibitor on NECA-mediated cell proliferation/migration. (a) Cell proliferation in presence (+) or absence (-) of NECA $(10 \mu \mathrm{M})$ and/or L-NAME $(100 \mu \mathrm{M})$ during 24 hours in normal (white bars) or preeclamptic pregnancies (grey bars). (b) Cell migration as in (a). ${ }^{*} P<0.05$ versus respective value in basal conditions. ${ }^{\dagger} P<0.05$ versus respective value in normal pregnancy. Values are expressed in fold of change considering respective basal condition (i.e., without any treatment) in normal or preeclamptic cells. Values in mean \pm SEM. Values in respective control column indicate $n$. All experiments were performed in duplicate.

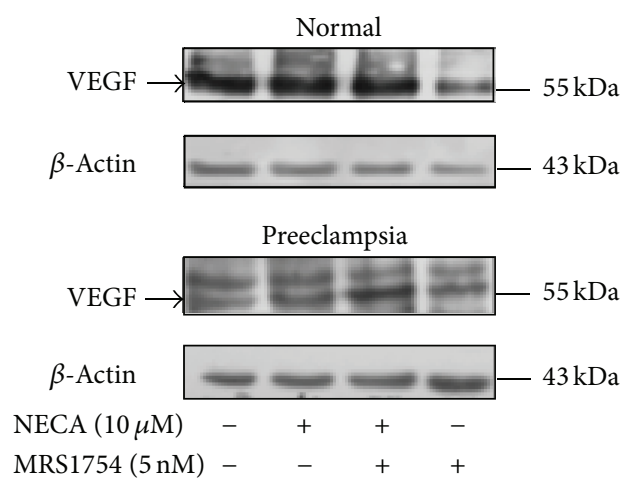

(a)
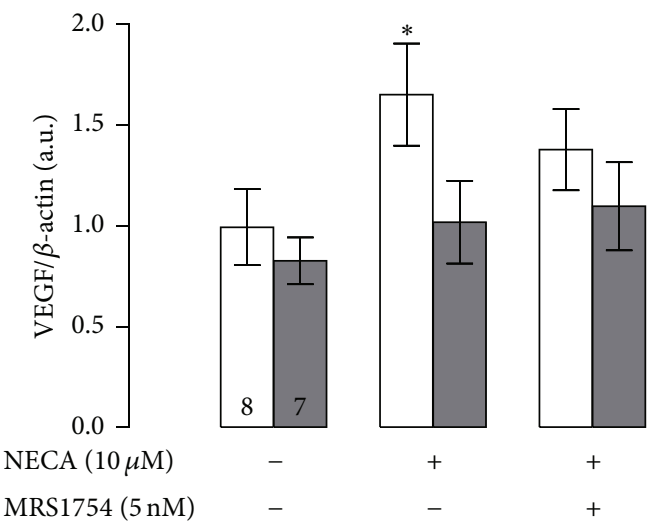

(b)

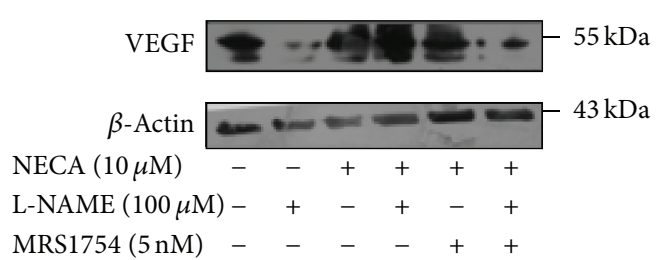

(c)

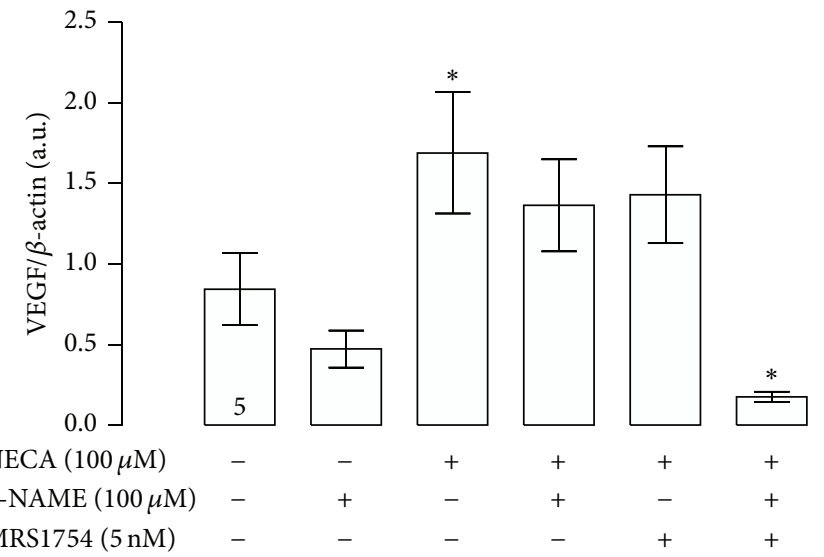

(d)

FIGURE 6: Effect of $\mathrm{A}_{2 \mathrm{~B}} \mathrm{AR}$ stimulation in the VEGF protein level. (a) Representative images of western blot for VEGF (55kDa) and $\beta$-actin $(43 \mathrm{kDa})$ in HUVEC from normal or preeclamptic pregnancies incubated in absence $(-)$ or presence of NECA (10 $\mu \mathrm{M})$ and/or MRS-1754 $(5 \mathrm{nM})$ during 12 hours. (b) Densitometry of the VEGF/ $\beta$-actin ratio as showed in (a). (c) Representative images of VEGF (55 kDa) and $\beta$ actin $(43 \mathrm{kDa})$ in HUVEC from normal pregnancies treated with NECA $(10 \mu \mathrm{M})$ and/or MRS-1754 $(5 \mathrm{nM})$ and/or L-NAME (100 $\mu \mathrm{M})$ during 12 hours. (d) Densitometry of the VEGF/ $\beta$-actin ratio as showed in (c). ${ }^{*} P<0.05$ versus basal condition in normal pregnancy. Values are mean \pm SEM. Values in respective control column indicate $n$. All experiments were performed in duplicate. 
under investigation and include direct and indirect actions on several different cell types and practically all adenosine receptors may be involved [23, 39]. Focusing on endothelial cells, either $\mathrm{A}_{2 \mathrm{~A}} \mathrm{AR}$ or $\mathrm{A}_{2 \mathrm{~B}} \mathrm{AR}$ has been shown to mediate the proliferative actions of adenosine in human retinal microvascular endothelial cells $[15,40]$, HUVEC $[22,29]$, or porcine coronary artery and rat aortic endothelial cells [28], while it remains still unclear if $\mathrm{A}_{1} \mathrm{AR}$ and $\mathrm{A}_{3} \mathrm{AR}$ are functionally expressed, and what role, if any, they play in endothelial cells.

Particularly, expression of $\mathrm{A}_{2 \mathrm{~B}} \mathrm{AR}$ in HUVEC and its participation in angiogenesis have been well characterized in the literature $[22,27,39,41-43]$, which is also supported by our results. Moreover, functional presence of $\mathrm{A}_{2 \mathrm{~B}} \mathrm{AR}$ leading to activation of NO/VEGF signaling pathway in cells derived from normal pregnancy is suggested because the NECAmediated augmentation in cell proliferation, nitrotyrosine formation, and VEGF protein abundance is inhibited by MRS-1754 coincubation. These results agree with previous observations regarding induction of $\mathrm{NO}$ production after $A_{2 A} A R / A_{2 B} A R$ stimulation in porcine carotid artery endothelial cells (PCAEC) [44], human iliac arterial endothelial cells (HIAEC) [45], and HUVEC [27, 29, 46, 47], as well as with others indicating adenosine mediated augmentation in the VEGF expression in many endothelial cells [29, 40, 41, 4853].

Moreover, our results in HUVEC derived from normal pregnancy suggest that $\mathrm{A}_{2 \mathrm{~B}} \mathrm{AR}$-mediated activation of $\mathrm{NO}$ synthesis would not be the unique pathway involved in the cell proliferation/migration in HUVEC. This is because NECA-mediated increase in cell proliferation/migration and VEGF protein abundance was only partially reverted by the NOS inhibitor, L-NAME, whereas coincubation with both inhibitors MRS-1754 ( $\mathrm{A}_{2 \mathrm{~B}} \mathrm{AR}$ antagonist) and L-NAME has additive effects upon these two NECA-mediated effects. It is unknown how NO/protein nitration may control cell proliferation and VEGF expression in HUVEC. However, potential mechanism might include activation of hypoxia inducible factor mediated by nitration [54].

In our study, we used the unspecific inhibitor of NOS, LNAME, in a concentration $(100 \mu \mathrm{M})$ that should be inhibiting all the isoforms of NOS according to the estimated value of $\mathrm{Ki}$ (neuronal NOS (nNOS, $15 \mathrm{nM}$ ), eNOS (39 nM), and inducible NOS (iNOS, $65 \mu \mathrm{M})$ ). Although our cell model expresses constitutively eNOS, we could not roll out the participation of other isoforms in our experimental data. Another limitation regarding importance of $\mathrm{NO}$ in our study is the use of nitrite measurements and nitrotyrosine formation as indirect markers for NO synthesis. Although both techniques have several advantages and disadvantages for estimating NO synthesis, it is clear that more direct measurement is required in order to elucidate participation of $\mathrm{NO}$ in the $\mathrm{A}_{2 \mathrm{~B}} \mathrm{AR}$ signaling pathway. Therefore, future studies should consider the use of more specific inhibitors for eNOS, or molecular biology techniques for suppressing or overexpressing eNOS.

4.3. Preeclampsia, Adenosine, and HUVEC Proliferation/ Migration. In the preeclampsia field, elevated level of plasma adenosine has been reported in the fetoplacental circulation
$[7,19,20]$, which reaches the micromolar range in umbilical vein; therefore it is feasible that under these conditions all adenosine receptors would be stimulated [18, 55]. Moreover, elevation of adenosine in the fetal circulation of preeclamptic pregnancies seems to be a phenomenon depending on the severity of the disease, since only children with alteration in the Doppler velocimetry of umbilical artery exhibit elevation in the adenosine level compared to normal pregnancy [20]. Causes and consequences of elevated extracellular adenosine concentration in preeclampsia are unclear.

We have previously documented that HUVECs isolated from late-onset preeclampsia exhibit high cell proliferation/migration, while in early onset preeclampsia these parameters were reduced in relation to women with normal pregnancy [29]. Interestingly, activation of $A_{2 A} A R$ was heterogeneous between late-onset preeclampsia and early onset preeclampsia. Thus, whereas late-onset preeclampsia was associated with a "basal" activation of the adenosine/NO/VEGF pathway, early onset preeclampsia exhibited a downregulation of this particularly via [29], suggesting that changes in cell proliferation/migration observed between late-onset preeclampsia and early onset preeclampsia may be explained by changes in the $\mathrm{A}_{2 \mathrm{~A}} \mathrm{AR} / \mathrm{NO} / \mathrm{VEGF}$ signaling pathway activation.

In the actual report, although we did not classify the women in late-onset or early onset preeclampsia, due to sample size, most of the preeclamptic women belong to group with early onset preeclampsia, as indicated by reduced gestational age at delivery. In addition, in order to avoid potential "basal" effect of high extracellular level of adenosine, we have performed all experiments in presence of adenosine deaminase. Under these experimental conditions, an increased protein abundance of $\mathrm{A}_{2 \mathrm{~B}} \mathrm{AR}$ associated with reduction in its function is present in HUVEC from preeclampsia. These results allow speculating the following. (1) Elevation in the $\mathrm{A}_{2 \mathrm{~B}} \mathrm{AR}$ observed in preeclampsia may be associated with activation of hypoxia inducible factor 1 alpha (HIF-1 $\alpha$ ) [56], since the $A_{2 B} A R$ promoter contains a functional binding site for HIF-1 $\alpha$ [57], which promotes $\mathrm{A}_{2 \mathrm{~B}} \mathrm{AR}$ expression in HUVEC [22]. (2) The reduced activation of $A_{2 B} A R$ observed in preeclampsia may be related to reduced availability of the receptor in the cell membrane. Indirect evidences for this hypothesis are elevated $\log \mathrm{EC}_{50}$ for NECA-mediated proliferation observed in HUVEC from preeclampsia compared to normal pregnancy. Clearly, more studies are required to elucidate the mechanisms linked with $\mathrm{A}_{2 \mathrm{~B}} \mathrm{AR}$ expression and activation in preeclampsia.

Result in this study suggests that $\mathrm{A}_{2 \mathrm{~B}} \mathrm{AR} / \mathrm{NO} / \mathrm{VEGF}$ pathway observed in normal pregnancy would be dysfunctional in HUVEC from preeclampsia. This idea is supported by the fact that although activation of $\mathrm{A}_{2 \mathrm{~B}} \mathrm{AR}$ is associated with nitration and cell proliferation, it was not related to VEGF protein expression. In this regard, Feoktistov and colleagues [22] have reported that hypoxia-mediated upregulation of $\mathrm{A}_{2 \mathrm{~B}} \mathrm{AR}$ in HUVEC has a functional impact, since only under this condition the $A_{2 B} A R$ was coupled to upregulation of VEGF. Our results partially agree with this concept, with respect to upregulation of $A_{2 B} A R$ in preeclampsia, a condition characterized by placental under perfusion $[2,3]$ 
and HIF-1 $\alpha$ activation [56]. Contrarily, we did not find an $\mathrm{A}_{2 \mathrm{~B}} \mathrm{AR}$-mediated VEGF expression in preeclampsia, whereas it was evidenced in cell from normal pregnancy. Apparent discrepancy may be related to experimental condition, since in the Feokstitov's report [22] they use a HUVEC cell line, rather than primary culture as we reported; and hypoxia was defined as $4.6 \%$ oxygen, which is considered normoxia for primary culture of HUVEC [58].

There are some intriguing results in our study that we would like to discuss. For instance, $A_{2 B} A R$ activation might not be associated with cell migration in either normal pregnancy or preeclampsia, because MRS-1754 was unable to block the stimulatory effect of NECA upon cell migration. Although we did not analyze the participation of other adenosine receptors in this particular study, it has been described previously that activation of $\mathrm{A}_{2 \mathrm{~A}} \mathrm{AR}$ increases cell migration in HUVEC from either normal or preeclamptic pregnancies [29]. Then, $A_{2 A} A R$, rather than $A_{2 B} A R$, may be involved in the cell migration during normal pregnancy and preeclampsia. Another intriguing result is the reduction in the nitrite levels (i.e., NO metabolites) in the culture medium of preeclamptic cells induced by coincubation with NECA and MRS-1754 (Figure 4(c)). As stated above, we could not roll out the participation of other adenosine receptors (except $\mathrm{A}_{2 \mathrm{~B}} \mathrm{AR}$ ) in this response.

\section{Conclusion}

HUVECs from normal pregnancies exhibit a functional presence of $\mathrm{A}_{2 \mathrm{~B}} \mathrm{AR}$, whose activation is associated with cell proliferation, mediated at least partially, via intracellular protein nitration and VEGF synthesis. On the other hand, cells from preeclampsia are characterized by upregulation in the $A_{2 B} A R$ protein expression, but its activity is diminished and might not be involved in the control of VEGF expression.

\section{Abbreviations}

NO: $\quad$ Nitric oxide

NOS: $\quad$ Nitric oxide synthase

VEGF: Vascular endothelial growth factor

$\mathrm{A}_{2 \mathrm{~A}} \mathrm{AR}: \quad \mathrm{A}_{2 \mathrm{~A}}$ adenosine receptor

$\mathrm{A}_{2 \mathrm{~B}} \mathrm{AR}: \quad \mathrm{A}_{2 \mathrm{~B}}$ adenosine receptor

L-NAME: NG-nitro-L-arginine methyl ester

NO: $\quad$ Nitric oxide

VEGF: Vascular endothelial growth factor

HUVECs: Human umbilical vein endothelial cells

hPMEC: Human placental microvascular endothelial cells.

\section{Conflict of Interests}

The authors declare that there is no conflict of interests.

\section{Authors' Contribution}

The work was carried out in collaboration between all authors. Jesenia Acurio and Carlos Escudero defined the research topic. Patricio Bertoglia defined diagnosis and included patients. Jesenia Acurio, Felipe Troncoso, and Carlos Escudero designed methods and performed experiments. Jesenia Acurio, Felipe Troncoso, and Carlos Escudero analyzed the data; Jesenia Acurio, Claudio Aguayo, Carlos Salomon, Luis Sobrevia, and Carlos Escudero interpreted the results and co-wrote the paper.

\section{Acknowledgments}

The authors are deeply grateful to midwives and medical staff in the Obstetrics and Gynecology Department of Hospital Clinico Herminda Martin, Chillan, Chile. They would like to thank all research staff at Vascular Physiology Laboratory and the Group of Investigation of Tumor Angiogenesis (GIANT) belonging to Universidad del Bío-Bío, as well as the Group of Research and Innovation in Vascular Health, for their technical support. This study was financed by Fondecyt Regular 1100684, 1110977, CONICYT 79112027, Anillos ACT73, DIUBB 122109 GI/EF.

\section{References}

[1] L. Duley, "The global impact of pre-eclampsia and eclampsia," Seminars in Perinatology, vol. 33, no. 3, pp. 130-137, 2009.

[2] E. Soto, R. Romero, J. P. Kusanovic et al., "Late-onset preeclampsia is associated with an imbalance of angiogenic and antiangiogenic factors in patients with and without placental lesions consistent with maternal underperfusion," Journal of MaternalFetal and Neonatal Medicine, vol. 25, no. 5, pp. 498-507, 2012.

[3] G. Ogge, T. Chaiworapongsa, R. Romero et al., "Placental lesions associated with maternal underperfusion are more frequent in early-onset than in late-onset preeclampsia," Journal of Perinatal Medicine, vol. 39, no. 6, pp. 641-652, 2011.

[4] S. Di Paolo, P. Volpe, G. Grandaliano et al., "Increased placental expression of tissue factor is associated with abnormal uterine and umbilical Doppler waveforms in severe preeclampsia with fetal growth restriction," Journal of Nephrology, vol. 16, no. 5, pp. 650-657, 2003.

[5] D. Marzioni, L. Tamagnone, L. Capparuccia et al., "Restricted innervation of uterus and placenta during pregnancy: evidence for a role of the repelling signal semaphorin 3A," Developmental Dynamics, vol. 231, no. 4, pp. 839-848, 2004.

[6] L. Carbillon, M. Uzan, and S. Uzan, "Pregnancy, vascular tone, and maternal hemodynamics: a crucial adaptation," Obstetrical and Gynecological Survey, vol. 55, no. 9, pp. 574-581, 2000.

[7] C. Escudero, P. Casanello, and L. Sobrevia, "Human equilibrative nucleoside transporters 1 and 2 may be differentially modulated by A2B adenosine receptors in placenta microvascular endothelial cells from pre-eclampsia," Placenta, vol. 29, no. 9, pp. 816-825, 2008.

[8] E. Sobrevia, F. Westermeier, C. Saloman et al., "Fetoplacental vascular pathophysiology in preeclampsia," in Recent Research Developments in Physiology, L. Sobrevia, Ed., vol. 1, pp. 105-158, Research Signpost, Kerala, India, 2012.

[9] J. M. Roberts, R. N. Taylor, T. J. Musci, G. M. Rodgers, C. A. Hubel, and M. K. McLaughlin, "Preeclampsia: an endothelial cell disorder," American Journal of Obstetrics and Gynecology, vol. 161, no. 5, pp. 1200-1204, 1989.

[10] J. M. Roberts, R. N. Taylor, and A. Goldfien, "Clinical and biochemical evidence of endothelial cell dysfunction in 
the pregnancy syndrome preeclampsia," American Journal of Hypertension, vol. 4, no. 8, pp. 700-708, 1991.

[11] A. C. Staff, K. Braekke, N. K. Harsem, T. Lyberg, and M. R. Holthe, "Circulating concentrations of sFlt1 (soluble fmslike tyrosine kinase 1) in fetal and maternal serum during pre-eclampsia," European Journal of Obstetrics Gynecology and Reproductive Biology, vol. 122, no. 1, pp. 33-39, 2005.

[12] L. Myatt, "Role of placenta in preeclampsia," Endocrine, vol. 19, no. 1, pp. 103-111, 2002.

[13] A. S. Kvehaugen, R. Dechend, H. B. Ramstad, R. Troisi, D. Fugelseth, and A. C. Staff, "Endothelial function and circulating biomarkers are disturbed in women and children after preeclampsia," Hypertension, vol. 58, no. 1, pp. 63-69, 2011.

[14] C. Escudero, C. Puebla, F. Westermeier, and L. Sobrevia, "Potential cell signalling mechanisms involved in differential placental angiogenesis in mild and severe pre-eclampsia," Current Vascular Pharmacology, vol. 7, no. 4, pp. 475-485, 2009.

[15] M. B. Grant, M. I. Davis, S. Caballero, I. Feoktistov, I. Biaggioni, and L. Belardinelli, "Proliferation, migration, and ERK activation in human retinal endothelial cells through A2B adenosine receptor stimulation," Investigative Ophthalmology and Visual Science, vol. 42, no. 9, pp. 2068-2073, 2001.

[16] M. E. Olah and G. L. Stiles, "The role of receptor structure in determining adenosine receptor activity," Pharmacology and Therapeutics, vol. 85, no. 2, pp. 55-75, 2000.

[17] K. A. Jacobson and Z. Gao, "Adenosine receptors as therapeutic targets," Nature Reviews Drug Discovery, vol. 5, no. 3, pp. 247264, 2006.

[18] B. B. Fredholm, A. P. Ijzerman, K. A. Jacobson, K.-N. Klotz, and J. Linden, "International Union of Pharmacology. XXV. Nomenclature and classification of adenosine receptors," Pharmacological Reviews, vol. 53, no. 4, pp. 527-552, 2001.

[19] Y. Yoneyama, R. Sawa, S. Suzuki, S. Shin, G. G. Power, and T. Araki, "The relationship between uterine artery Doppler velocimetry and umbilical venous adenosine levels in pregnancies complicated by preeclampsia," American Journal of Obstetrics and Gynecology, vol. 174, no. 1, part 1, pp. 267-271, 1996.

[20] J. Espinoza, A. F. Espinoza, and G. G. Power, "High fetal plasma adenosine concentration: a role for the fetus in preeclampsia?" American Journal of Obstetrics and Gynecology, vol. 205, no. 5, pp. 485-487, 2011.

[21] F. von Versen-Höynck, A. Rajakumar, S. A. Bainbridge, M. J. Gallaher, J. M. Roberts, and R. W. Powers, "Human placental adenosine receptor expression is elevated in preeclampsia and hypoxia increases expression of the A2A receptor," Placenta, vol. 30, no. 5, pp. 434-442, 2009.

[22] I. Feoktistov, S. Ryzhov, H. Zhong et al., "Hypoxia modulates adenosine receptors in human endothelial and smooth muscle cells toward an A2B angiogenic phenotype," Hypertension, vol. 44, no. 5, pp. 649-654, 2004.

[23] T. H. Adair, "Growth regulation of the vascular system: an emerging role for adenosine," American Journal of PhysiologyRegulatory Integrative and Comparative Physiology, vol. 289, no. 2, pp. R283-R296, 2005.

[24] S. Koch and L. Claesson-Welsh, "Signal transduction by vascular endothelial growth factor receptors," Cold Spring Harbor Perspectives in Medicine, vol. 437, no. 2, pp. 169-183, 2011.

[25] S. E. Maynard and S. A. Karumanchi, "Angiogenic factors and preeclampsia," Seminars in Nephrology, vol. 31, no. 1, pp. 33-46, 2011.
[26] E. Poniedzialek-Czajkowska, B. Marciniak, Z. Kimber-Trojnar, B. Leszczyńska-Gorzelak, and J. Oleszczuk, "Nitric oxide in normal and preeclamptic pregnancy," Current Pharmaceutical Biotechnology, vol. 12, no. 5, pp. 743-749, 2011.

[27] A. W. Wyatt, J. R. Steinert, C. P. D. Wheeler-Jones et al., "Early activation of the $\mathrm{p} 42 / \mathrm{p} 44 \mathrm{MAPK}$ pathway mediates adenosineinduced nitric oxide production in human endothelial cells: a novel calcium-insensitive mechanism," FASEB Journal, vol. 16, no. 12, pp. 1584-1594, 2002.

[28] R. K. Dubey, D. G. Gillespie, and E. K. Jackson, "A2B adenosine receptors stimulate growth of porcine and rat arterial endothelial cells," Hypertension, vol. 39, no. 2, part 2, pp. 530-535, 2002.

[29] C. Escudero, P. Bertoglia, M. Hernadez et al., "Impaired A(2A) adenosine receptor/nitric oxide/VEGF signaling pathway in fetal endothelium during late- and early-onset preeclampsia," Purinergic Signalling, vol. 9, no. 2, pp. 215-226, 2013.

[30] R. González P, R. Gómez M, R. Castro S et al., "A national birth weight distribution curve according to gestational age in Chile from 1993 to 2000," Revista Medica de Chile, vol. 132, no. 10, pp. 1155-1165, 2004.

[31] P. Casanello, A. Torres, F. Sanhueza et al., "Equilibrative nucleoside transporter 1 expression is downregulated by hypoxia in human umbilical vein endothelium," Circulation Research, vol. 97, no. 1, pp. 16-24, 2005.

[32] S. Rey, R. Del Rio, and R. Iturriaga, "Contribution of endothelin1 to the enhanced carotid body chemosensory responses induced by chronic intermittent hypoxia," Brain Research, vol. 1086, no. 1, pp. 152-159, 2006.

[33] T. Y. Khong, F. De Wolf, W. B. Robertson, and I. Brosens, "Inadequate maternal vascular response to placentation in pregnancies complicated by pre-eclampsia and by small-for-gestational age infants," British Journal of Obstetrics and Gynaecology, vol. 93, no. 10, pp. 1049-1059, 1986.

[34] J. M. Roberts and C. A. Hubel, "The two stage model of preeclampsia: variations on the theme," Placenta, vol. 30, pp. 3237, 2009.

[35] G. J. Burton, A. W. Woods, E. Jauniaux, and J. C. P. Kingdom, "Rheological and physiological consequences of conversion of the maternal spiral arteries for uteroplacental blood flow during human pregnancy," Placenta, vol. 30, no. 6, pp. 473-482, 2009.

[36] L. Myatt, "Review: reactive oxygen and nitrogen species and functional adaptation of the placenta," Placenta, vol. 31, pp. S66S69, 2010.

[37] L. Myatt and X. Cui, "Oxidative stress in the placenta," Histochemistry and Cell Biology, vol. 122, no. 4, pp. 369-382, 2004.

[38] C. Escudero and L. Sobrevia, "A hypothesis for preeclampsia: adenosine and inducible nitric oxide synthase in human placental microvascular endothelium," Placenta, vol. 29, no. 6, pp. 469-483, 2008.

[39] I. Feoktistov, I. Biaggioni, and B. N. Cronstein, "Adenosine receptors in wound healing, fibrosis and angiogenesis," Handbook of Experimental Pharmacology, vol. 193, pp. 383-397, 2009.

[40] M. B. Grant, R. W. Tarnuzzer, S. Caballero et al., "Adenosine receptor activation induces vascular endothelial growth factor in human retinal endothelial cells," Circulation Research, vol. 85, no. 8, pp. 699-706, 1999.

[41] I. Feoktistov, A. E. Goldstein, S. Ryzhov et al., "Differential expression of adenosine receptors in human endothelial cells: role of A2B receptors in angiogenic factor regulation," Circulation Research, vol. 90, no. 5, pp. 531-538, 2002. 
[42] Y. Fang and M. E. Olah, "Cyclic AMP-dependent, protein kinase A-independent activation of extracellular signalregulated kinase $1 / 2$ following adenosine receptor stimulation in human umbilical vein endothelial cells: role of exchange protein activated by cAMP 1 (Epac1)," Journal of Pharmacology and Experimental Therapeutics, vol. 322, no. 3, pp. 1189-1200, 2007.

[43] H. Li, S. Y. Jin, H. J. Son, J. H. Seo, and G. B. Jeong, "Caffeine-induced endothelial cell death and the inhibition of angiogenesis," Anatomy \& Cell Biology, vol. 46, no. 1, pp. 57-67, 2013.

[44] J.-M. Li, R. A. Fenton, B. S. Cutler, and J. G. Dobson Jr., "Adenosine enhances nitric oxide production by vascular endothelial cells," American Journal of Physiology-Cell Physiology, vol. 269, no. 2, part 1, pp. C519-C523, 1995.

[45] J. Li, R. A. Fenton, H. B. Wheeler et al., "Adenosine A(2a) receptors increase arterial endothelial cell nritric oxide," Journal of Surgical Research, vol. 80, no. 2, pp. 357-364, 1998.

[46] L. Sobrevia, A. Nadal, D. L. Yudilevich, and G. E. Mann, "Activation of L-arginine transport (system $\mathrm{y}+$ ) and nitric oxide synthase by elevated glucose and insulin in human endothelial cells," Journal of Physiology, vol. 490, part 3, pp. 775-781, 1996.

[47] G. Vásquez, F. Sanhueza, R. Vásquez et al., "Role of adenosine transport in gestational diabetes-induced L-arginine transport and nitric oxide synthesis in human umbilical vein endothelium," Journal of Physiology, vol. 560, part 1, pp. 111-122, 2004.

[48] E. M. George, K. Cockrell, T. H. Adair, and J. P. Granger, "Regulation of sFlt-1 and VEGF secretion by adenosine under hypoxic conditions in rat placental villous explants," American Journal of Physiology-Regulatory Integrative and Comparative Physiology, vol. 299, no. 6, pp. R1629-R1633, 2010.

[49] S. Gessi, E. Fogli, V. Sacchetto et al., "Adenosine modulates HIF$1 \alpha$, VEGF, IL- 8 , and foam cell formation in a human model of hypoxic foam cells," Arteriosclerosis, Thrombosis, and Vascular Biology, vol. 30, no. 1, pp. 90-97, 2010.

[50] J. Gu, B. R. Ito, A. Sartin, N. Frascogna, M. Moore, and T. H. Adair, "Inhibition of adenosine kinase induces expression of VEGF mRNA and protein in myocardial myoblasts," American Journal of Physiology-Heart and Circulatory Physiology, vol. 279, no. 5, pp. H2116-H2123, 2000.

[51] M. E. Olah and F. L. Roudabush, "Down-regulation of vascular endothelial growth factor expression after $\mathrm{A}(2 \mathrm{~A})$ adenosine receptor activation in PC12 pheochromocytoma cells," Journal of Pharmacology and Experimental Therapeutics, vol. 293, no. 3, pp. 779-787, 2000.

[52] S. Ryzhov, J. L. McCaleb, A. E. Goldstein, I. Biaggioni, and I. Feoktistov, "Role of adenosine receptors in the regulation of angiogenic factors and neovascularization in hypoxia," Journal of Pharmacology and Experimental Therapeutics, vol. 320, no. 2, pp. 565-572, 2007.

[53] D. Valladares, C. Quezada, P. Montecinos et al., "Adenosine A2B receptor mediates an increase on VEGF-A production in rat kidney glomeruli," Biochemical and Biophysical Research Communications, vol. 366, no. 1, pp. 180-185, 2008.

[54] A. Riaño, D. Ortiz-Masià, M. Velázquez, S. Calatayud, J. V. Esplugues, and M. D. Barrachina, "Nitric oxide induces HIF$1 \alpha$ stabilization and expression of intestinal trefoil factor in the damaged rat jejunum and modulates ulcer healing," Journal of Gastroenterology, vol. 46, no. 5, pp. 565-576, 2011.

[55] B. B. Fredholm, E. Irenius, B. Kull, and G. Schulte, "Comparison of the potency of adenosine as an agonist at human adenosine receptors expressed in Chinese hamster ovary cells," Biochemical Pharmacology, vol. 61, no. 4, pp. 443-448, 2001.
[56] R. Tal, "The role of hypoxia and hypoxia-inducible factor-lalpha in preeclampsia pathogenesis," Biology of Reproduction, vol. 87, no. 6, p. 134, 2012.

[57] T. Kong, K. A. Westerman, M. Faigle, H. K. Eltzschig, and S. P. Colgan, "HIF-dependent induction of adenosine A2B receptor in hypoxia," FASEB Journal, vol. 20, no. 13, pp. 2242-2250, 2006.

[58] P. Casanello, B. Krause, E. Torres et al., "Reduced 1-arginine transport and nitric oxide synthesis in human umbilical vein endothelial cells from intrauterine growth restriction pregnancies is not further altered by hypoxia," Placenta, vol. 30, no. 7, pp. 625-633, 2009. 

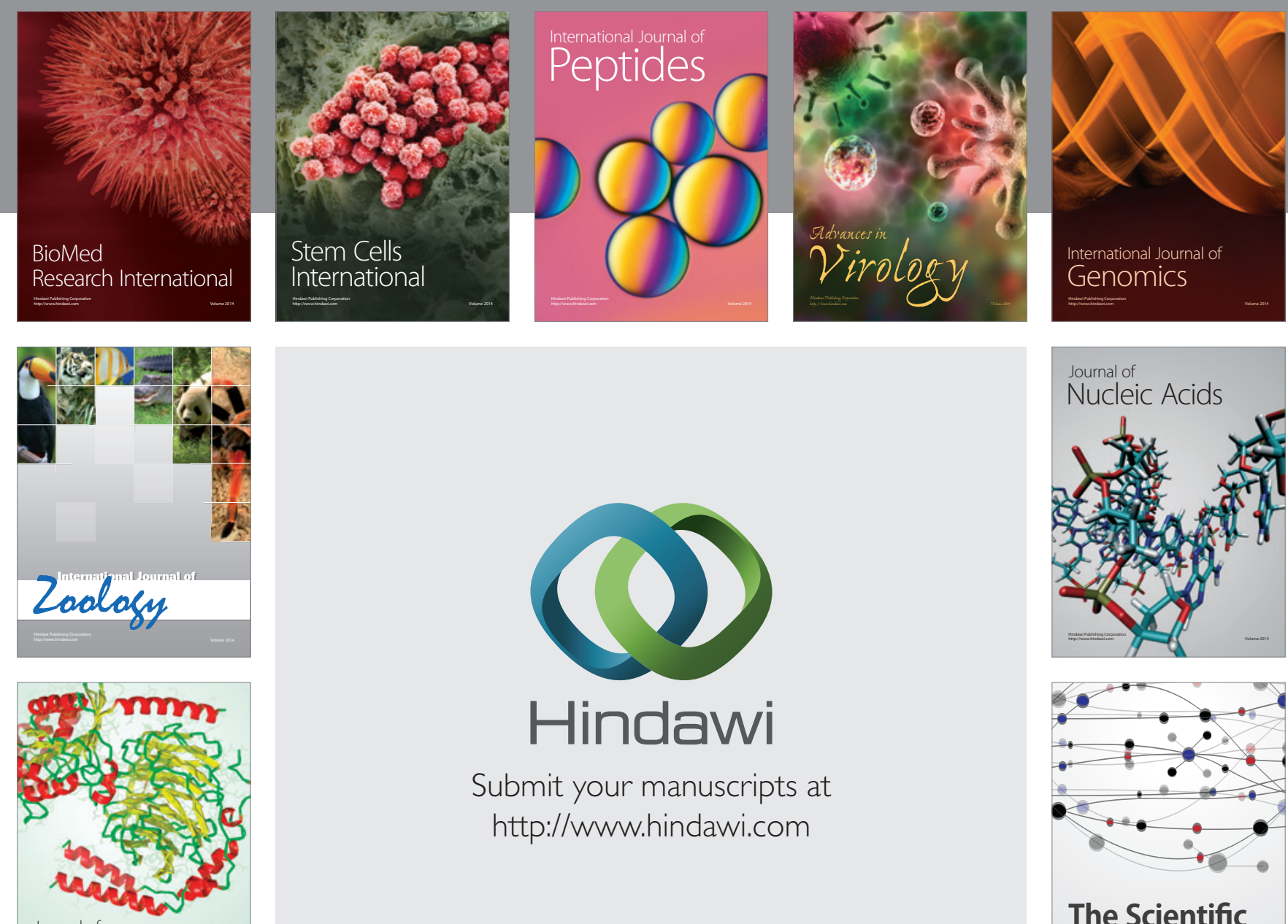

Submit your manuscripts at

http://www.hindawi.com

Journal of
Signal Transduction
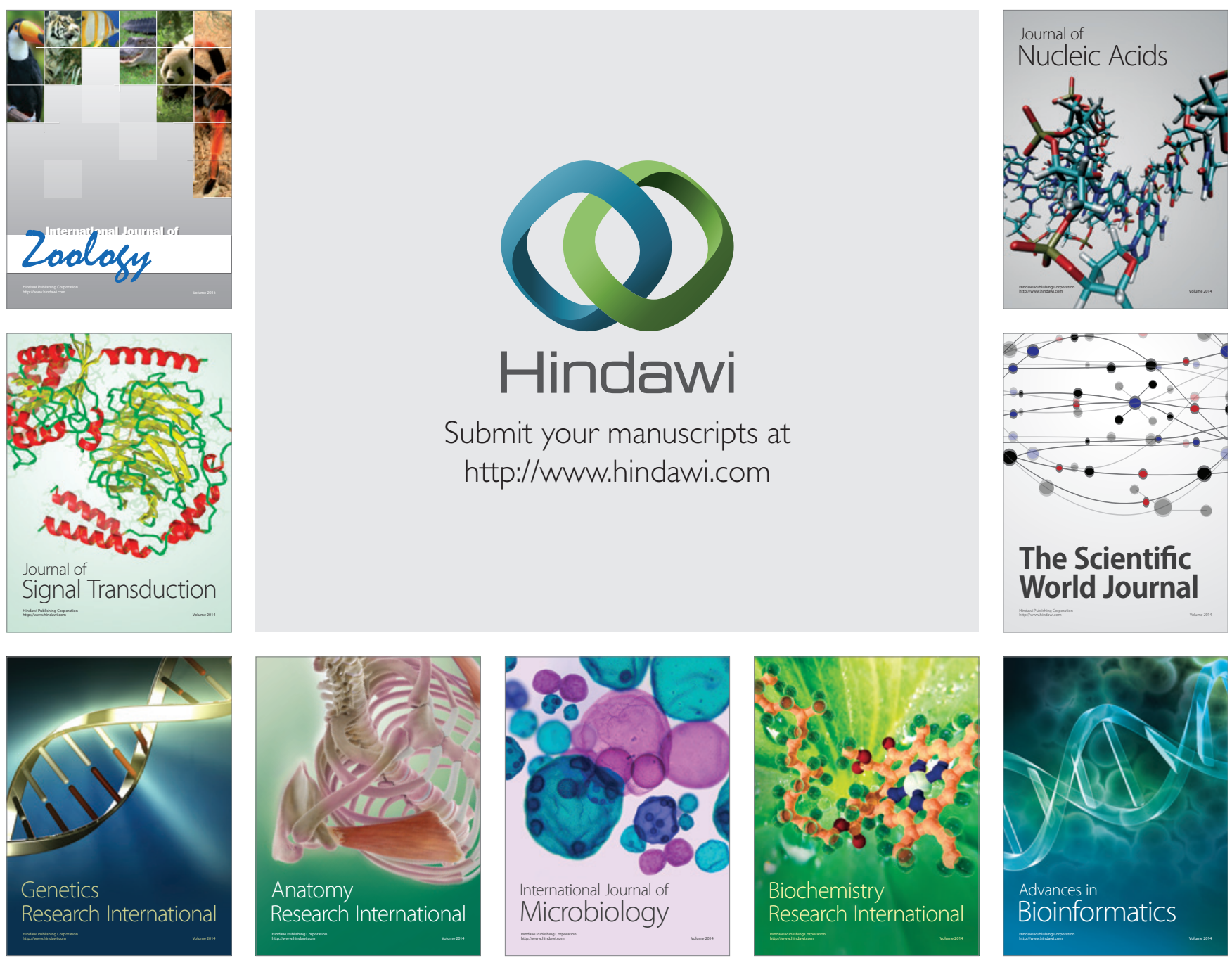

The Scientific World Journal
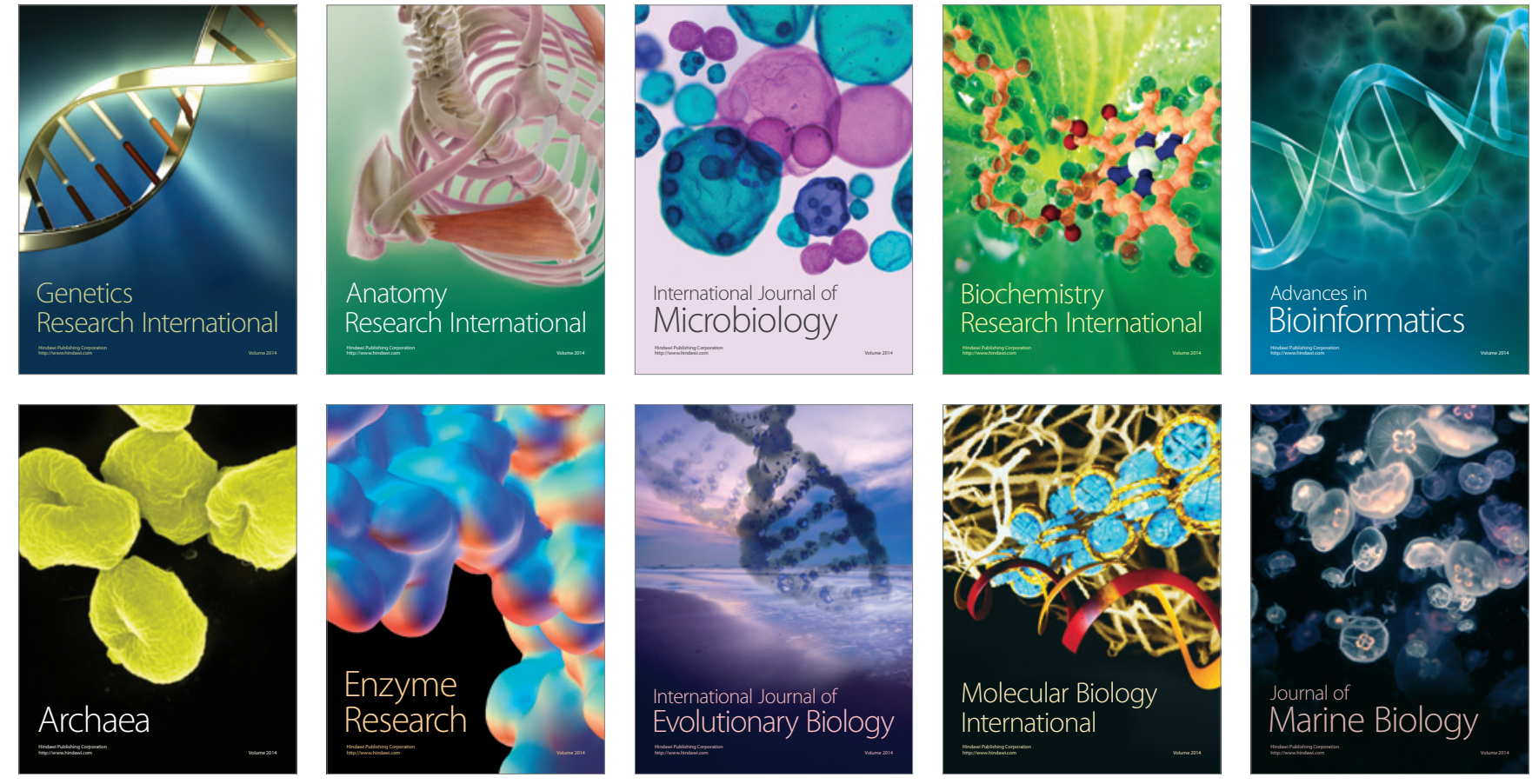